\title{
Inflammatory cutaneous lesions in inflammatory bowel disease treated with Vedolizumab or Ustekinumab: an ECCO CONFER multicentre case series
}

Phillips FM, Verstockt B, Sebastian S, Ribaldone DG, Vavricka S, Katsanos K, Slattery E, de Suray N, Flores C, Fries W, Vincenzi F, Capoferro E, Bachmann O, Kopylov U; ECCO CONFER investigators.

1. Frank M Phillips, frankmphillips@hotmail.com NIHR Nottingham Digestive Diseases Biomedical Research Centre, Nottingham University Hospitals, Nottingham, UK

2. Bram Verstockt, bram.verstockt@uzleuven.be University Hospitals Leuven, Gastroenterology and Hepatology, Leuven, Belgium KU Leuven, Chronic Diseases, Metabolism and Ageing, TARGID-IBD unit, Leuven, Belgium

3. Shaji Sebastian, shaji.sebastian@hey.nhs.uk Hull and East Yorkshire Hospitals NHS Trust, Inflammatory Bowel Disease Unit, Hull, UK University of Hull and York, Hull York Medical School, Hull, UK

4. Davide Ribaldone, davrib 1998@yahoo.com University of Turin, Surgical Sciences, Turin, Italy

5. Stephan Vavricka, stephan.vavricka@usz.ch University Hospital Zurich, Medicine, Zurich, Switzerland

6. Konstantinos Katsanos, khkhostas@hotmail.com University of Ioannina School of Medical Sciences, Gastroenterology, Ioannina, Greece

7. Eoin Slattery, eoin.slattery2@hse.ie University Hospital Galway, Gastroenterology, Galway, Ireland

8. Nicholas de Suray, nicholas.desuray@gmail.com Grand Hopital de Charleroi, Gastroenterology and Hepatology, Charleroi, Belgium University Hospital Saint-Luc, Gastroenterology and Hepatology, Bruxelles, Belgium

9. Cristina Flores, cfloresgastro@gmail.com Hospital de Clinicas de Porto Alegre, Gastroenterology, Rio Grande do Sul, Brazil

(C) The Author(s) 2020. Published by Oxford University Press on behalf of European Crohn's and Colitis Organisation. All rights reserved. For permissions, please email:

journals.permissions@oup.com 
10. Walter Fries, fwalter@unime.it

University Messina, Clinical Unit for Chronic Bowel Disorders, Messina, Italy,

11. Francesca Vincenzi, francivin@libero.it

University of Parma, Gastroenterology and Endoscopy Unit, Parma, Italy

12. Elvira Capoferro, capoferro.elvira@gmail.com

University of Parma, Gastroenterology and Endoscopy Unit, Parma, Italy

Sacro Cuore Don Calabria of Negrar, Negrar, Italy

13. Oliver Bachmann, o.bachmann@siloah.de

Siloah St. Trudpert Klinikum, Pforzheim, Germany

14. Uri Kopylov, ukopylov@gmail.com

Sheba Medical Centre, Gastroenterology, Ramat Gan, Israel

Presented at the $14^{\text {th }}$ Congress of ECCO, March 2019, Copenhagen, Denmark. 


\section{Abstract}

This was a multicentre case series supported by the European Crohn's and Colitis Organisation (ECCO) and, performed as part of the Collaborative Network of Exceptionally Rare case reports (CONFER) project. The aim was to report on whether cutaneous lesions associated with inflammatory bowel disease (IBD) and refractory to standard medical therapy including anti-TNFs, would respond to the newer biologic agents Ustekinumab (UST) or Vedolizumab (VDZ). This report includes 28 patients with cutaneous lesions form 14 centres, all of whom had failed immunomodulator and anti-TNF therapy. Metastatic Crohn's disease (MCD) was diagnosed in 10 patients: UST led to remission in 5 cases and partial response in 4 cases, with a single report of VDZ inducing remission. All cases of MCD treated with UST responded after the first or second dose, whilst the median time for the 5 cases that attained remission was 5 months. Pyoderma gangrenosum (PG) was diagnosed in 4 cases: 3 of these attained remission with UST (median time to remission 4 months) whilst one case did not respond to VDZ. There were 7 cases of erythema nodosum (EN): UST led to remission in 4 cases and partial response in 1 case whilst VDZ had partial response in 2 cases and non-response in 2 cases. There were 7 single cases of other inflammatory lesions. In summary, UST appears to be useful for different cutaneous lesions including MCD, PG and EN, whilst VDZ does not appear to be useful for lesions that are independent of disease activity. 


\section{Introduction}

Inflammatory bowel disease (IBD), which includes Crohn's disease (CD) and ulcerative colitis (UC), are often associated with extraintestinal manifestations, occurring in $43 \%$ of patients with $C D$ and $31 \%$ with UC in one large population study. ${ }^{1}$ These can be just as or more debilitating than the underlying intestinal inflammation.

The skin is one of the most common extraintestinal organ systems involved, occurring in $14.9 \%$ of a recent cohort when cutaenoues lesions due to nutrient deficiencies and medications were excluded. The most common cutaneous lesion in IBD is erythema nodosum (EN), which is a reactive lesion that closely parallels intestinal disease activity. ${ }^{3}$ Pyoderma gangrenosum (PG) is the second most common cutaneous lesion and amongst the most debilitating. Both can usually be diagnosed clinically without the need for biopsy. Whilst treatment for EN focuses on treating the underlying intestinal disease, PG often occurs independently of disease activity and requires systemic immunosuppression.

One of the rarest cutaneous lesions in IBD is metastatic Crohn disease (MCD), also known as cutaneous Crohn disease. This is characterised by non-caseating granulomas with similar histology to intestinal Crohn's disease but at sites anatomically distinct from the gastrointestinal tract. ${ }^{4}$ It can occur independent of disease activity.

Cutaneous lesions such as these can be particularly distressing and are often difficult to treat even with anti-TNF agents. There are two new biologic agents, ustekinumab (UST) and vedolizumab (VDZ), now used widely in the treatment of IBD. UST is a humanised monoclonal antibody that targets the common p40 subunit of IL-12 and IL-23 cytokines. The phase III UNITI trials established UST as an effective treatment for $C D,{ }^{5}$ whilst the recently published phase III UNIFI trials show it is also an effective treatment for UC too. ${ }^{6} \mathrm{VDZ}$ is a humanised monoclonal antibody that targets $\alpha 4 \beta 7$ integrin, which is expressed by a subset of gastrointestinal-homing T-lymphocytes. Theoretically there should be little activity on those EIMs that are independent of disease activity. A populationbased study showed that VDZ was not useful for EIM prevention, ${ }^{7}$ whilst a recent systematic review concluded VDZ was not useful for cutaneous lesions. ${ }^{8}$ However, there have been reports of improvements in EIMs felt to be independent of disease activity such as PG, uveitis and ankylosing spondylitis. ${ }^{9,10}$

This collaborative case series looks at the efficacy of both UST and VDZ to treat different types of anti-TNF refractory cutaneous lesions in IBD.

\section{Case Report}

This was a retrospective multicentre case series supported by the European Crohn's and Colitis Organisation (ECCO), and performed as part of the ECCO Collaborative Network for Exceptionally Rare case reports (CONFER) project. A call to all ECCO members was made to report on cutaneous lesions in IBD treated with UST or VDZ. This excluded psoriasiform lesions, oral lesions and perianal lesions. Clinical data was recorded in a standardized data collection form including: demographics, Montreal classification, previous medications, location, type and morphology of cutaneous lesion, treatments for the lesion, and time to response or remission. 
This study includes 28 patients with cutaneous lesions from 14 different centres, diagnosed with the help of dermatology specialists. 20 patients were female and the median age range was 37 years old; 23 had CD and 5 had UC whilst 19 were treated with UST and 11 with VDZ (2 patients were treated with both). As far as we are aware, all patients were treated with UST and VDZ according to the manufacturer's recommendations. All patients had failed both immunomodulator and anti-TNF therapy, whilst the use of topical therapies was ongoing in some cases. The results are summarised in table 1 and figures 1-6 show cases included here.

Metastatic Crohn's disease (MCD) was diagnosed in 10 patients (see table 2), 9 confirmed by histology and the other diagnosed clinically by an experienced dermatologist. UST therapy led to remission in 5 cases and partial response in 4 cases. Two of these cases had failed VDZ, whilst there was a single report of VDZ leading to remission in MCD. All the cases of MCD treated with UST responded after either the first or second dose, whilst for the 5 cases that attained remission, the median time for this was 5 months. The distribution of $C D$ was ileocolonic in 8 cases and colonic in 2 cases. Luminal Crohn's disease was active in 7 cases and quiescent in the other 3 cases. The location of the MCD lesion was truncal in 3 cases, genital in 4 cases, groin in 2 cases, and groin and genitals in one case. The morphology of the MCD lesions was ulcerative in 4 cases, papular in 3 cases and plaque-like in 3 cases.

Pyoderma gangrenosum (PG) was diagnosed in 4 cases: 3 of these attained remission with UST (median time to remission 4 months) whilst the other case did not respond to VDZ. Erythema nodosum (ED) was diagnosed in 7 cases: 2 cases had non-response to VDZ with subsequent remission to UST; UST led to remission in a further 2 cases and partial response in 1 case; VDZ had partial response in a further 2 cases.

In addition, there were 7 single cases of other inflammatory lesions, which included: a case of leukocytoclastic vasculitis that attained remission with VDZ, a case of HS with partial response to UST, and a case of dissecting cellulitis of the scalp that did not respond to UST.

\section{Discussion}

This case series describes the efficacy of the newer biologic agents for a series of cutaneous lesions refractory to standard immunomodulator and anti-TNF therapy. Its limitations are that reporting is retrospective and histology was not available in all cases, although it is common for dermatological diagnoses and assessment of response or remission to be made on clinical grounds.

Ten patients with MCD were included, one of the largest case series of this rare cutaneous manifestation of $C D$ to date. Although MCD can occur independent of disease activity, 7 of the 10 cases had active luminal disease. Morphology is variable, ${ }^{4}$ which is reflected in our cases with approximately equal numbers of ulcers, plaques and nodules. Location is also variable with a predilection for moist skin creases such as the perineal, inguinal, abdominal and sub-mammary areas. Seven of our cases were located to the groin or genitals, and 3 to the trunk, which may represent a predilection for these areas or difficulties in treating lesions in the groin and genital areas. It has previously been reported that MCD is more common in patients with CD colitis, and this is reflected in this study, with all 10 patients having colonic involvement. 
Experience of the treatment of MCD mainly comes from case reports with various treatment modalities having been used, including steroids, immunomodulators, antibiotics, hyperbaric oxygen ${ }^{11}$, anti-TNF biologic agents ${ }^{12,13}$ and surgical debridement. ${ }^{14}$ More recently, there have been two case reports of ustekinumab being used for MCD affecting the groin and genitals, one of which is included in this series. ${ }^{15,16}$ Given the rarity of MCD and the prominence in this study, it perhaps reflects the difficulties in treating this condition with standard medical therapy. It is therefore significant that all 9 patients with MCD treated with UST in this series responded after the first or second dose, with 5 of these patients attaining complete remission in a median time of 5 months. This indicates a potentially strong signal for the efficacy of ustekinumab in MCD.

EN occurs in up to $15 \%$ of CD and $10 \%$ of UC. ${ }^{17}$ There were 7 cases in this series, with UST leading to response or remission in all 5 of its cases. Two of these patients had failed VDZ prior to UST, and another two had a partial response to VDZ. Given that EN lesions parallel disease activity, the response of UST and VDZ likely reflected the response to the underlying IBD activity.

The relationship of PG to IBD activity is not entirely clear and treatment of intestinal disease does not always help with PG. The mainstay of treatment is with systemic steroids, with or without topical treatments. Anti-TNF agents have also been used successfully in refractory cases. ${ }^{18,19}$ There have also been some case reports of the successful use of UST in PG not associated with IBD, ${ }^{20}$ including one case which demonstrated high levels of IL-23 in the lesion. ${ }^{21}$ Our study included 4 patients with IBD-associated PG, 3 of whom attained remission with UST and the other did not respond to VDZ. This indicates the potential usefulness of UST for IBD-associated PG.

Of the other inflammatory lesions, there was one case of leukocytoclastic vasculitis showing complete response to VDZ, which correlates with experience that shows most cases resolve with treatment of the underlying IBD. ${ }^{22,23}$ There was a single case of response of HS to UST. A small open label study of UST for HS has previously indicated its potential usefulness. ${ }^{24}$ In summary, UST appears to be useful for different cutaneous lesions including MCD, PG and EN, whilst VDZ does not appear to be useful for lesions that are independent of disease activity. 


\section{Acknowledgements}

ECCO CONFER projects are based on an initiative introduced by ECCO to support individual investigators in developing rare case series by collecting enough similar cases among the IBD Community. This support includes dissemination of a call for similar cases, as well as assessment of the feasibility of the cases by the ECCO CONFER Steering Committee. It does not include any financial support nor any input in the scientific collection of the data, the analysis or the publication of the data collected. ECCO, and/or any of its staff members, may not be held liable for any information published in good faith in the ECCO CONFER articles. 


\section{References}

1. Vavricka SR, Brun L, Ballabeni P, Pittet V, Prinz Vavricka BM, Zeitz J, Rogler G, Schoepfer AM. Frequency and risk factors for extraintestinal manifestations in the Swiss inflammatory bowel disease cohort. Am J Gastroenterol 2011; 106: 110-119.

2. Vide J, Osório F, Costa-Silva M, Lopes S, Azevedo F, Camila Dias C, Magina S, Magro F. Cutaneous Morbidity Among Inflammatory Bowel Disease Patients: A Cohort Study. J Crohns Colitis 2018; 12(4): 442-451.

3. Trost LB, McDonnell JK. Important cutaneous manifestations of Inflammatory Bowel Disease. Postgrad Med J 2005;81: 580-58510.

4. Siroy A, Wasman J. Metastatic Crohn disease: a rare cutaneous entity. Arch Pathol Lab Med 2012; 136(3): 329-32.

5. Feagan BG, Sandborn WJ, Gasink C, Jacobstein D, Lang Y, Friedman JR, et al. Ustekinumab as induction and maintenance therapy for Crohn's Disease. N Engl J Med 2016; 375(20): 19461960.

6. Sands BE, Sandborn WJ, Panaccione R, O'Brien CD, Zhang H, Johanns J, Adedokun OJ, Li K, Peyrin-Biroulet L, Van Assche G, Danese S, Targan S, Abreu MT, Hisamatsu T, Szapary P, Marano C; UNIFI Study Group. Ustekinumab as Induction and Maintenance Therapy for Ulcerative Colitis. N EngI J Med 2019; 381(13): 1201-1214.

7. Dubinsky MC, Cross RK, Sandborn WJ, Long M, Song X, Shi N, Ding Y, Eichner S, Pappalardo B, Ganguli A, Wang A. Extraintestinal manifestations in Vedolizumab and Anti-TNF-treated patients With Inflammatory Bowel Disease. Inflamm Bowel Dis 2018.

8. Chateau T, Bonovas S, Le Berre C, Mathieu N, Danese S, Peyrin-Biroulet. Vedolizumab Treatment in Extra-Intestinal Manifestations in Inflammatory Bowel Disease: A Systematic Review. J Crohns Colitis 2019; 13(12): 1569-1577. 
9. Fleisher M, Marsal J, Lee SD, Frado LE, Parian A, Korelitz BI, Feagan BG. Effects of Vedolizumab therapy on extraintestinal manifestations in Inflammatory Bowel Disease. Dig Dis Sci 2018; 63(4): 825-833.

10. Tadbiri S, Peyrin-Biroulet L, Serrero M, Filippi J, Pariente B, Roblin X, Buisson A, Stefanescu C, Trang-Poisson C, Altwegg R, Marteau P, Vaysse T, Bourrier A, Nancey S, Laharie D, Allez M, Savoye G, Gilletta C, Gagniere C, Vuitton L, Viennot S, Aubourg A, Pelletier AL, Bouguen G, Abitbol V, Fumery M, Claudepierre P, Bouhnik Y, Amiot A; GETAID OBSERV-IBD study group. Impact of vedolizumab therapy on extra-intestinal manifestations in patients with inflammatory bowel disease: a multicentre cohort study nested in the OBSERV-IBD cohort. Aliment Pharmacol Ther 2018; 47(4): 485-493.

11. Brady CE 3rd, Cooley BJ, Davis JC. Healing of severe perineal and cutaneous Crohn's disease with hyperbaric oxygen. Gastroenterology 1989; 97(3): 756-760.

12. Miller AM, Elliott PR, Fink R, Connell W. Rapid response of severe refractory metastatic Crohn's disease to infliximab. J Gastroenterol Hepatol 2001; 16(8): 940-942.

13. Lestre S, Ramos J, Joao A, Serrao V. Cutaneous Crohn's disease presenting as genital warts: successful treatment with adalimumab. Eur J Dermatol 201; 20: 504-505

14. Williams N, Scott NA, Watson JS, Irving MH. Surgical management of perineal and metastatic cutaneous Crohn's disease. Br J Surg 1993; 80(12): 1596-1598.

15. Abdat R, Markova A, Farraye FA, Lichtman MK. Ustekinumab for the treatment of cutaneous Crohn's disease. Dermatol Online J 2016; 22(10).

16. Argyriou K, Khan M, Samuel S. Multiple unusual ulcerated skin lesions in a Crohn's Disease patient. Gastroenterology 2018; 155(5): e17-e18

17. Ribaldone DG, Pellicano R, Actis GC. The gut and the Inflammatory Bowel Diseases insideout: the extra-intestinal manifestations. Minerva Gastroenterol Dietol. 2019 Apr 16. doi: 10.23736/S1121-421X.19.02577-7. [Epub ahead of print] 
18. Brooklyn TN, Dunnill MG, Shetty A, Bowden JJ., Williams JD, Griffiths CE, Forbes A, Greenwood R, Probert CS. Infliximab for the treatment of pyoderma gangrenosum: a randomised, double blind, placebo-controlled trial. Gut 2006; 55: 505-50910.

19. Alkhouri N, Hupertz V, Mahajan L. Adalimumab treatment for peristomal pyoderma gangrenosum associated with Crohn's disease. Inflamm Bowel Dis 2009; 15: 803-80610

20. Low ZM, Mar A. Treatment of severe recalcitrant pyoderma gangrenosum with ustekinumab. Australasian Journal of Dermatology

21. Guenova E, Teske A, Fehrenbacher B, Hoerber S, Adamczyk A, Schaller M, Hoetzenecker W, Biedermann T. Interleukin 23 expression in pyoderama gangrenosum and targeted therapy with ustekinumab. Arch Dermatol 2011; 147(10): 1203-5.

22. Akbulut S, Ozaslan E, Topal F, Albayrak L, Kayhan B, Efe C. Ulcerative colitis presenting as leukocytoclastic vasculitis of skin. World J Gastroenterol 2008: 14; 2448.

23. Tsiamoulos Z, Karamanolis G, Polymeros D, Triantafyllou K, Oikonomopoulos T. Leukocytoclastic vasculitis as an onset symptom of Crohn's disease. Case Rep Gastroenterol 2008; 2: 410-41410.

24. Blok JL, Li K, Brodmerkel C, Horvátovich P, Jonkman MF, Horváth B. Ustekinumab in hidradenitis suppurativa: clinical results and a search for potential biomarkers in serum. $\mathrm{Br} \mathrm{J}$ Dermatol 2016; 174(4): 839-46. 
Table 1: Treatments and outcomes of the different cutaneous lesion types

\begin{tabular}{|c|c|c|c|c|c|c|c|}
\hline & $\mathbf{N}=$ & $\begin{array}{l}\text { Luminal } \\
\text { activity }\end{array}$ & $\begin{array}{l}\text { Previous } \\
\text { anti-TNF } \\
\text { therapy }\end{array}$ & $\begin{array}{l}\text { Mean } \\
\text { duration of } \\
\text { lesion prior } \\
\text { to UST or } \\
\text { VDZ } \\
\text { starting }\end{array}$ & $\begin{array}{l}\text { Concomitant } \\
\text { therapy }\end{array}$ & Ustekinumab & Vedolizumab \\
\hline $\begin{array}{l}\text { Metastatic } \\
\text { Crohn's disease }\end{array}$ & 10 & 7 & $\begin{array}{l}4 \text { cases } \\
\text { failed anti- } \\
\text { TNF } \\
6 \text { cases } \\
\text { had anti- } \\
\text { TNF prior } \\
\text { to lesion } \\
\text { developing }\end{array}$ & 10 months & $\begin{array}{l}\text { Methotrexate } \\
\text { in } 6 \text { cases } \\
\text { Azathioprine } \\
\text { in } 1 \text { case } \\
\text { Topical } \\
\text { therapy in } 1 \\
\text { case }\end{array}$ & $\begin{array}{l}\text { Remission in } \\
5 \text { cases } \\
\text { Response in } \\
4 \text { cases }\end{array}$ & $\begin{array}{l}\text { Remission in } \\
1 \text { case } \\
\text { Non- } \\
\text { response in } 2 \\
\text { cases }\end{array}$ \\
\hline $\begin{array}{l}\text { Pyoderma } \\
\text { gangrenosum }\end{array}$ & 4 & 3 & $\begin{array}{l}2 \text { cases } \\
\text { failed anti- } \\
\text { TNF } \\
2 \text { cases } \\
\text { had anti- } \\
\text { TNF prior } \\
\text { to lesion } \\
\text { developing }\end{array}$ & 5 months & $\begin{array}{l}\text { Topical } \\
\text { therapy i } \\
\text { cases }\end{array}$ & $\begin{array}{l}\text { Remission in } \\
3 \text { case }\end{array}$ & $\begin{array}{l}\text { Non- } \\
\text { response in } 1 \\
\text { case }\end{array}$ \\
\hline $\begin{array}{l}\text { Erythema } \\
\text { nodosum }\end{array}$ & 7 & 6 & $\begin{array}{l}3 \text { cases } \\
\text { failed anti- } \\
\text { TNF } \\
4 \text { cases } \\
\text { had anti- } \\
\text { TNF prior } \\
\text { to lesion } \\
\text { developing } \\
\end{array}$ & & $\begin{array}{l}\text { Topical } \\
\text { therapy in } 2 \\
\text { cases } \\
\text { Methotrexate } \\
\text { in } 1 \text { case } \\
\text { Azathioprine } \\
\text { in } 1 \text { case }\end{array}$ & $\begin{array}{l}\text { Remission in } \\
4 \text { cases } \\
\text { Response in } \\
1 \text { case }\end{array}$ & $\begin{array}{l}\text { Response in } \\
2 \text { cases } \\
\text { Non- } \\
\text { response in } 2 \\
\text { cases }\end{array}$ \\
\hline $\begin{array}{l}\text { Leukocytoclastic } \\
\text { vasculitis }\end{array}$ & 1 & 1 & $\begin{array}{l}\text { Anti-TNF } \\
\text { prior to } \\
\text { lesion } \\
\text { developing }\end{array}$ & 4 months & Azathioprine & & $\begin{array}{l}\text { Remission in } \\
1 \text { case }\end{array}$ \\
\hline $\begin{array}{l}\text { Hidradenitis } \\
\text { suppurativa }\end{array}$ & 1 & 1 & $\begin{array}{l}\text { Failed } \\
\text { anti-TNF } \\
\text { for } 2 \\
\text { months }\end{array}$ & 2 months & Triamcinolone & $\begin{array}{l}\text { Response in } \\
1 \text { case }\end{array}$ & \\
\hline $\begin{array}{l}\text { Dissecting } \\
\text { cellulitis of the } \\
\text { scalp }\end{array}$ & 1 & 0 & $\begin{array}{l}\text { Failed } \\
\text { anti-TNF } \\
\text { for } 2 \\
\text { months }\end{array}$ & 2 months & None & $\begin{array}{l}\text { Non- } \\
\text { response in } 1 \\
\text { case }\end{array}$ & \\
\hline $\begin{array}{l}\text { Unspecified } \\
\text { inflammatory } \\
\text { lesions }\end{array}$ & 4 & 1 & $\begin{array}{l}\text { Failed } \\
\text { anti-TNF } \\
\text { for } 1 \\
\text { month } \\
2 \text { cases } \\
\text { already on } \\
\text { VDZ when } \\
\text { lesion } \\
\text { appeared } \\
\end{array}$ & $<1$ month & $\begin{array}{l}\text { None in } 3 \\
\text { cases } \\
\text { Steroid in } 1 \\
\text { case }\end{array}$ & & $\begin{array}{l}\text { Response in } \\
2 \text { cases } \\
\text { Non- } \\
\text { response in } 2 \\
\text { cases }\end{array}$ \\
\hline
\end{tabular}


Table 2: Individual cases of metastatic Crohn's disease

\begin{tabular}{|c|c|c|c|c|c|c|c|c|}
\hline Age/gender & $\begin{array}{l}\text { Lesion } \\
\text { location }\end{array}$ & $\begin{array}{l}\text { Lesion } \\
\text { type }\end{array}$ & Diagnosis & $\begin{array}{l}\text { Luminal } \\
\text { activity }\end{array}$ & $\begin{array}{l}\text { VDZ } \\
\text { or } \\
\text { UST } \\
\text { use }\end{array}$ & $\begin{array}{l}\text { Concomitant } \\
\text { medications }\end{array}$ & Response & Remission \\
\hline $52 / \mathrm{F}$ & Genitals & $\begin{array}{l}\text { Plaque- } \\
\text { like }\end{array}$ & Biopsy & Quiescent & UST & Methotrexate & Month 2 & Month 4 \\
\hline $57 / F$ & $\begin{array}{l}\text { Genitals \& } \\
\text { groin }\end{array}$ & Papular & Biopsy & Active & UST & Methotrexate & Month 2 & Month 6 \\
\hline $17 / M$ & Genitals & Papular & Biopsy & Active & UST & Methotrexate & Month 3 & $\begin{array}{l}\text { Not } \\
\text { achieved }\end{array}$ \\
\hline $47 / F$ & Trunk & $\begin{array}{l}\text { Plaque- } \\
\text { like }\end{array}$ & Biopsy & Quiescent & UST & Methotrexate & Month 2 & $\begin{array}{l}\text { Not } \\
\text { achieved }\end{array}$ \\
\hline $62 / M$ & Trunk & Ulcer & Biopsy & Active & UST & Methotrexate & Month 3 & Month 5 \\
\hline $60 / F$ & Genitals & Ulcer & Biopsy & Quiescent & UST & Methotrexate & $\begin{array}{l}\text { Month } \\
12\end{array}$ & $\begin{array}{l}\text { Not } \\
\text { achieved }\end{array}$ \\
\hline $68 / F$ & Genitals & $\begin{array}{l}\text { Plaque- } \\
\text { like }\end{array}$ & Biopsy & Active & VDZ & None & Month 6 & Month 12 \\
\hline $35 / F$ & Groin & Papular & Biopsy & Active & UST & None & Month 1 & Month 4 \\
\hline $24 / M$ & Groin & Ulcer & Biopsy & Active & UST & $\begin{array}{l}\text { Topical } \\
\text { therapy }\end{array}$ & Month 2 & Month 12 \\
\hline $47 / F$ & Trunk & Ulcer & Clinically & Active & UST & Azathioprine & Month 2 & $\begin{array}{l}\text { Not } \\
\text { achieved }\end{array}$ \\
\hline
\end{tabular}




\section{Case of metastatic Crohn disease: partial resolution with UST}

Courtesy of Oliver Bachman

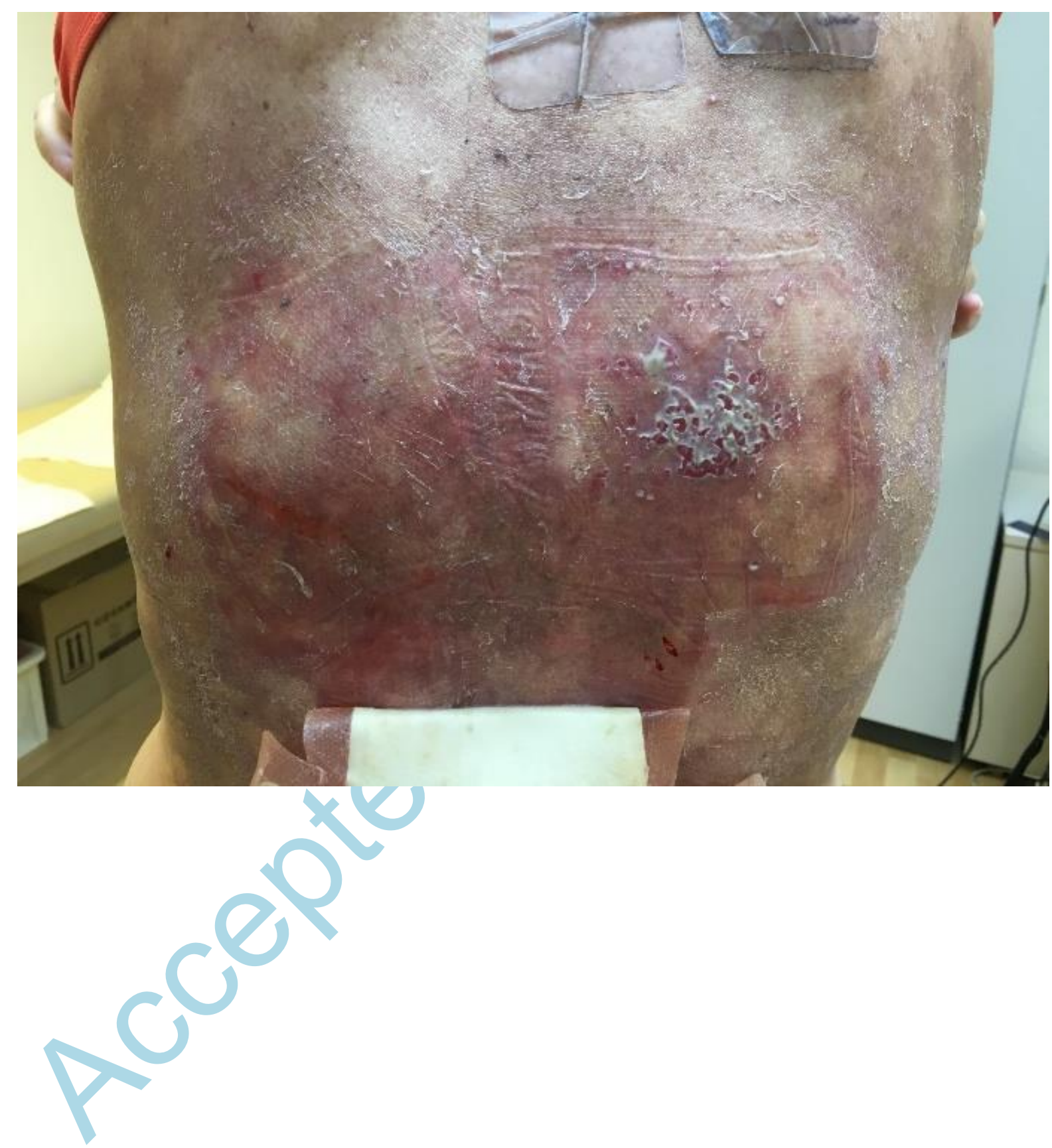


Pyoderma gangrenosum: complete remission with UST

Courtesy of Bram Verstockt

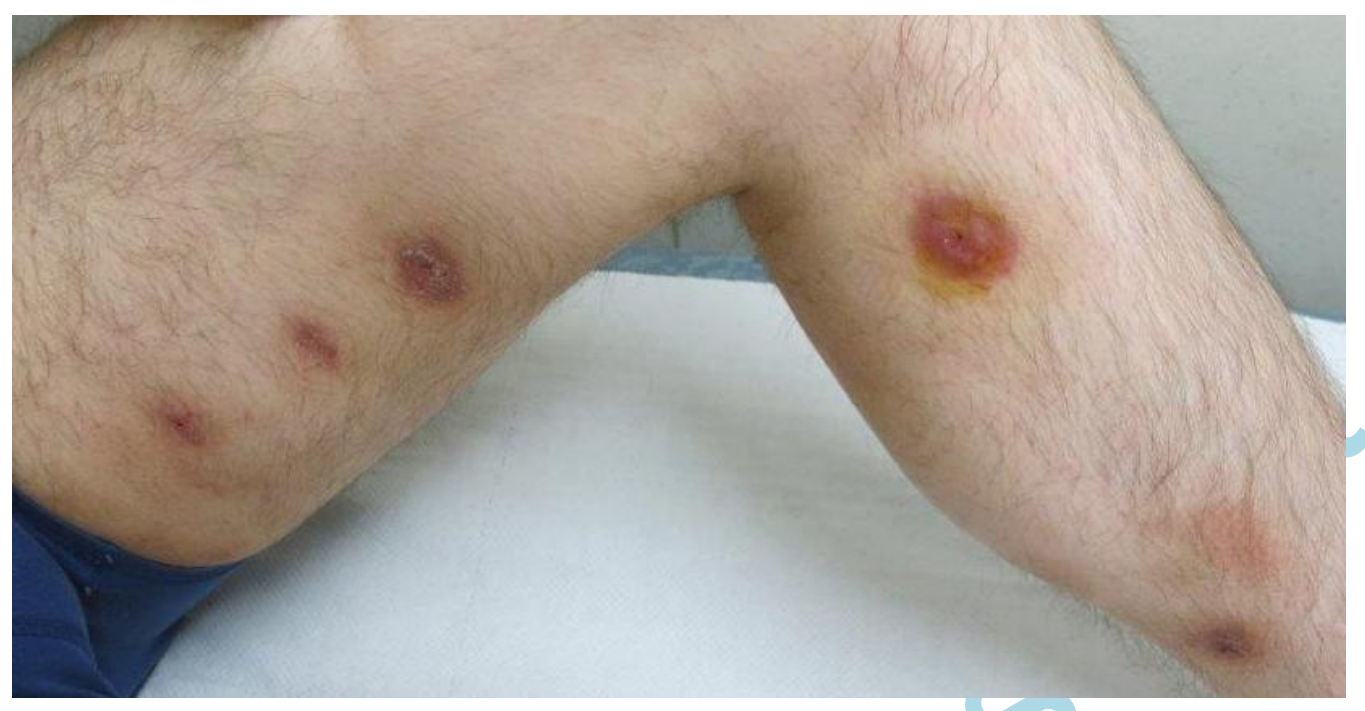


Case of peristomal pyoderma gangrenosum: complete remission with UST

Courtesy of Nicolas de Suray

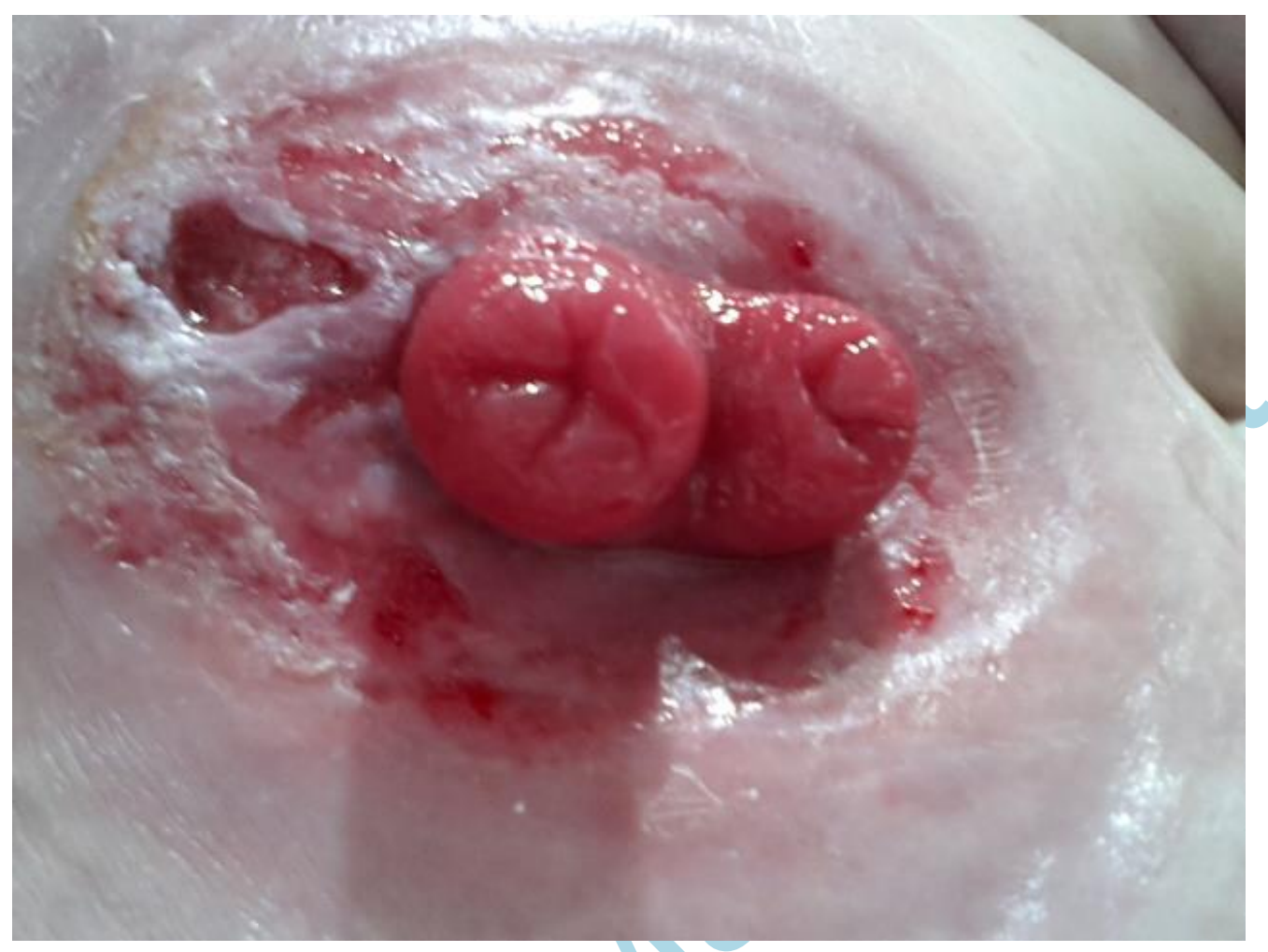


Case of erythema nodosum: no response to VDZ but subsequent remission with UST Courtesy of Bram Verstockt

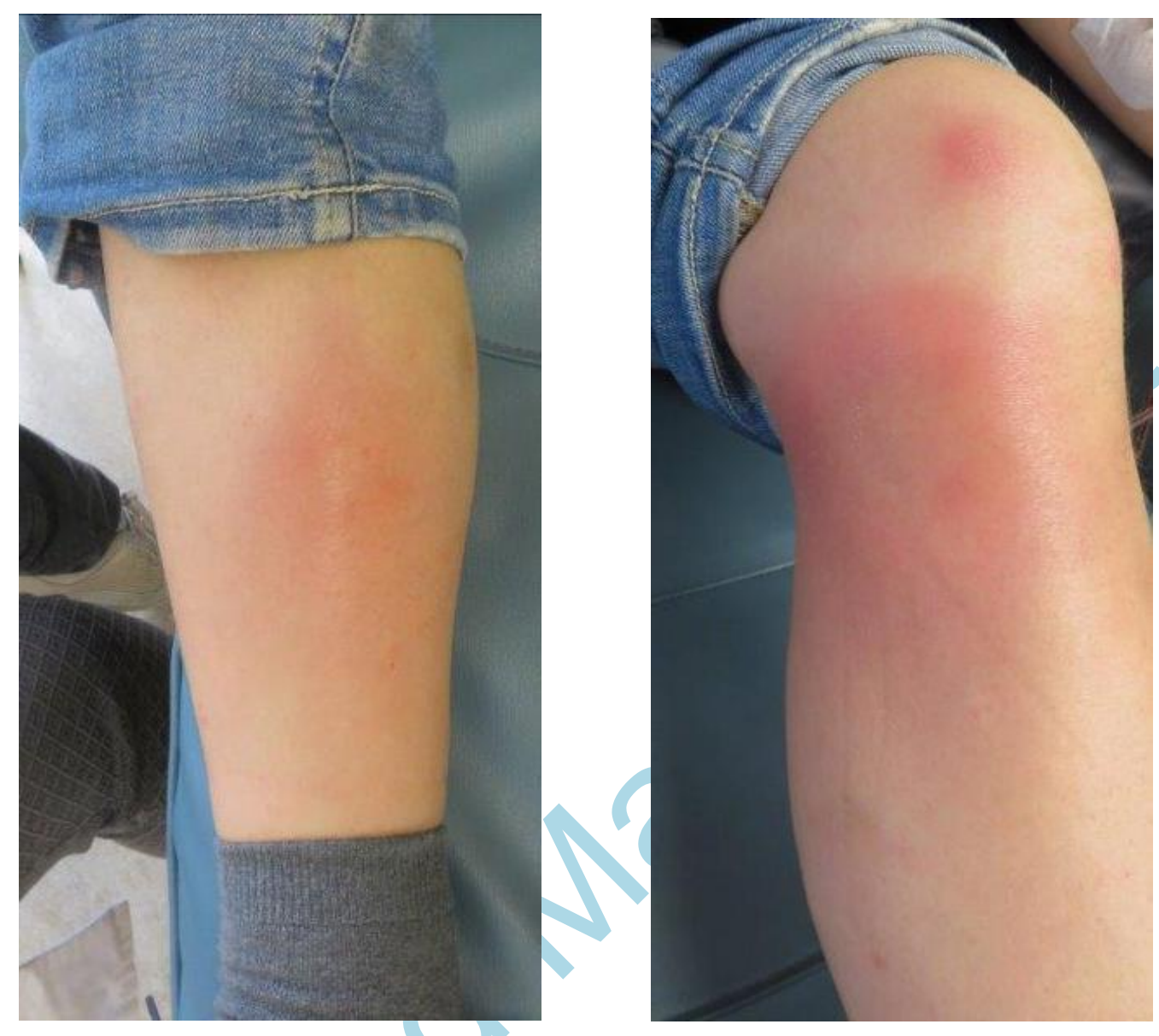




\section{Case of dissecting cellulitis of the scalp: no response to UST}

\section{Courtesy of Bram Verstockt}

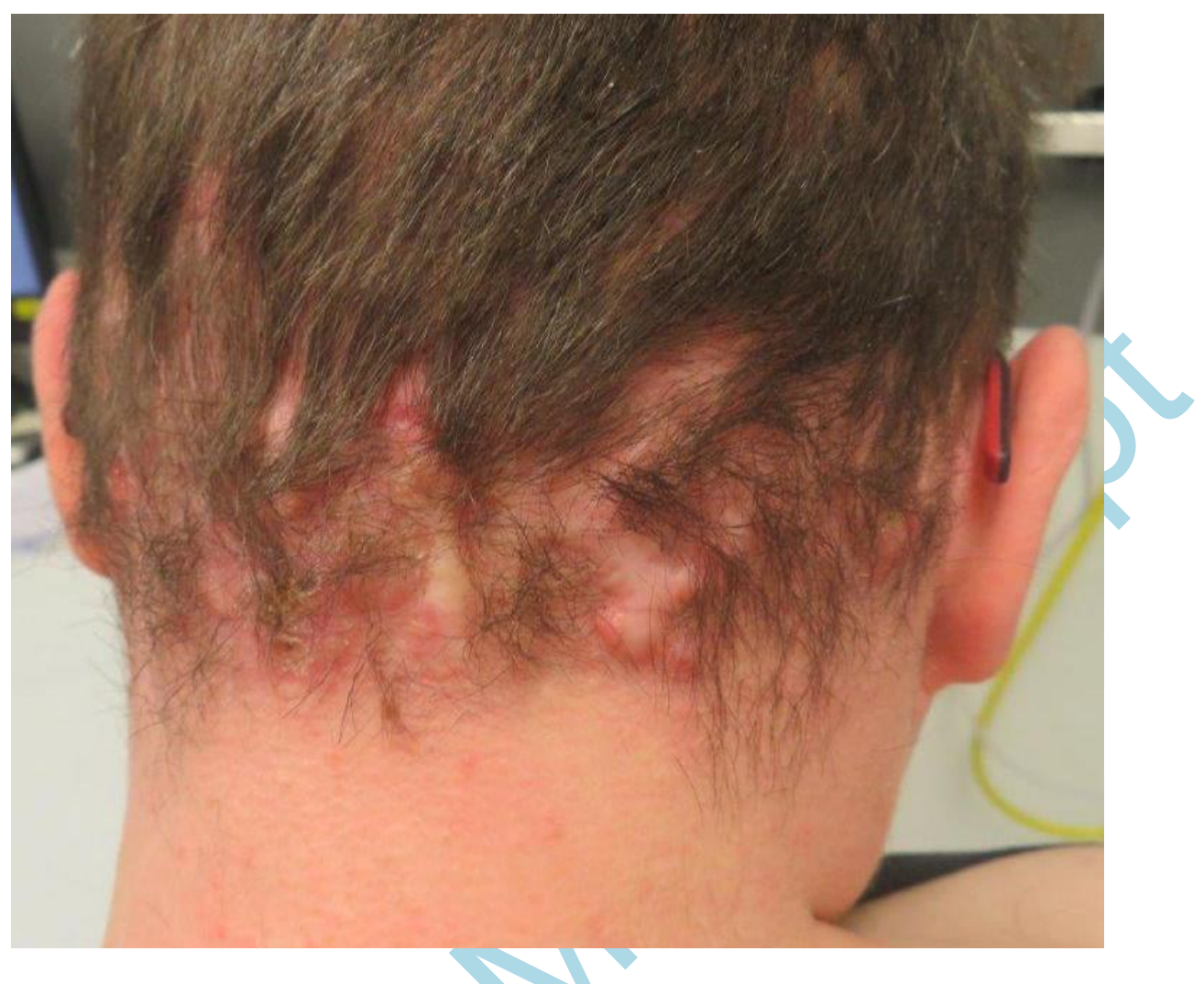


Case of leucocytoclastic vasculitis: complete remission with VDZ

Courtesy of Cristina Flores

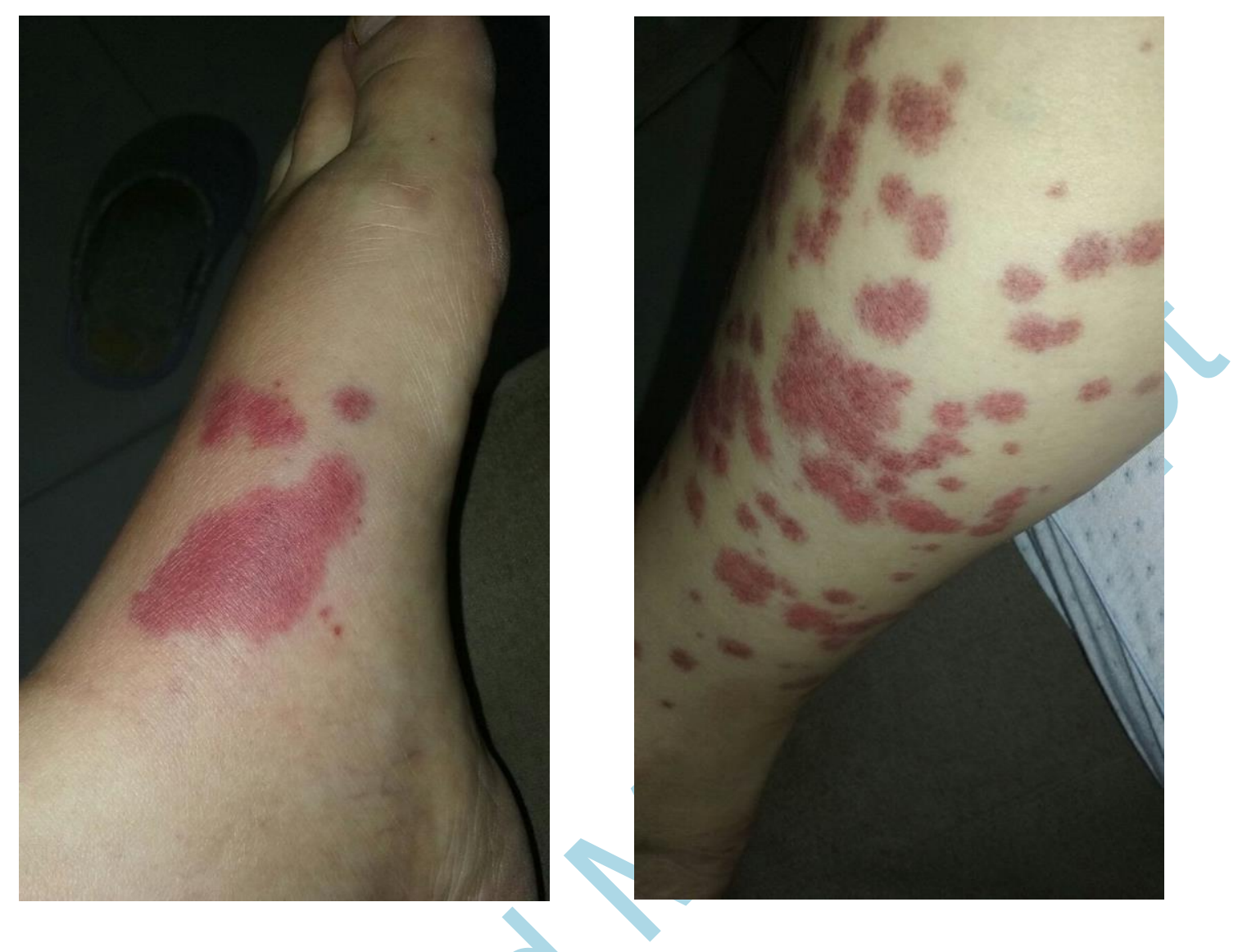

Consent

Patient consent was obtained for the publication of all photographs. 


\section{Authors contributions:}

FP: Principle Investigator for the study, conceived the study idea, contributed 1 case and prepared the manuscript. BV: contributed 7 cases and critiqued the manuscript. SS: contributed 6 cases and critiqued the manuscript. DR: contributed 3 cases and critiqued the manuscript. SV: contributed 2 cases and critiqued the manuscript. KK: contributed 2 cases and critiqued the manuscript. ES: contributed 1 case and critiqued the manuscript. NdS: contributed 1 case and critiqued the manuscript. CF: contributed 1 case and critiqued the manuscript. WF: contributed 1 case and critiqued the manuscript. FV: contributed 1 case and critiqued the manuscript. EC: contributed 1 case and critiqued the manuscript. OB: contributed 1 case and critiqued the manuscript. UK: Case Manager for the study, supervised the project and critiqued the manuscript. All authors approved the final version

\section{Conflicts of interest}

FP: none. BV: financial support for research from Pfizer; lecture fees from Abbvie, Ferring, Takeda Pharmaceuticals, Janssen and R Biopharm; consultancy fees from Janssen and Sandoz. SS: research grants from Takeda, AbbVie, Biogen, Pfizer, Warner Chilcott, Ferring, MSD, Biohit and Celgene; serves on the advisory boards of Takeda, AbbVie, Merck, Ferring, Pharmacocosmos, Warner Chilcott, Janssen, Falk Pharma, Biohit, TriGenix, Cellgene and Tillots Pharma; received speaker fees from Abbvie, Jaansen, Merck, Warner Chilcott and Falk Pharma. DR: none. SV: none. KK: none. ES: none. NdS: advisory board member for Takeda and Janssen; speaker fees from Takeda. CF: none. WF: none. FV: none. EC: none. OB: personal fees from Takeda Pharma, Shield Therapeutics, Ferring Pharmaceuticals, Pfizer, CED Service GmbH, Janssen Pharmaceutica, Merck Sharp \& Dohme, Abbvie, Astellas Pharma, Biogen, Falk Pharma GmbH, Bristol-Myers Squibb, Tillotts; grants from German Center for Infection Research. UK: research support from Takeda, Janssen, Medtronic; lecture/ advisory fees from Abbvie, Takeda, Janssen, MSD Medtronic

\section{Funding}

No specific funding has been received for this project. 